\title{
'Not that of mere accident, but of humane treatment': Natural Increase and 'Amelioration' on Grand Sable Estate, St Vincent
}

\author{
S.D. Smith (Brasenose College, University of Oxford) \\ simon.smith@bnc.ox.ac.uk
}

04.09.2017

\begin{abstract}
This article investigates the demographic history of Grand Sable sugar estate in nineteenthcentury St Vincent. Exceptionally for a Caribbean plantation, Grand Sable's enslaved population achieved natural increase (a surplus of births over deaths). Pro-slavery campaigners seized on this achievement to support the cause of gradualist amelioration and to oppose metropolitan regulation of slavery, especially emancipation. Explanations of demographic success advanced by opponents of abolition are found wanting and alternatives proposed that are more consistent with the surviving evidence. The role played by anomalies in shaping discourse on both sides of the slavery debate is highlighted.
\end{abstract}

\section{Keywords}

demography, slavery, abolition, amelioration, St Vincent 


\section{Introduction}

In scientific discourse, anomalies (or exceptions to the rule) have the potential to challenge established beliefs, resulting in the modification or abandonment of prevailing orthodoxies if the contradictions they generate are severe and prolonged. ${ }^{1}$ This paper considers the role of anomalies in contemporary debates leading to British abolition of the transatlantic slave trade in 1807 and particularly the Slavery Abolition Bill of 1833 . The principal focus is the foundation and population history of Grand Sable, a sugar plantation located on the island colony of St Vincent. This estate's extraordinary rates of reproduction formed the basis of anti-emancipation propaganda. Grand Sable has not previously featured in either the historical demography of slavery and the role of anomalies has also been neglected in studies of nineteenth-century abolitionist discourse.

The paper is structured as follows. In the introduction, the use made of demographic exceptions by pro and anti-slavery campaigners is illustrated with reference to the abolition debates of the late eighteenth century and the emancipation debates of the early nineteenth century. Section two documents the foundation of Grand Sable. The third section discusses pro-slavery explanations of Grand Sable's reproductive success. Section four re-evaluates the estate's population history by applying modern techniques to historical data. The final concluding section summarises how the Grand Sable contributes to understanding of contemporary debates over gradualist emancipation and the historical demography of slavery. 


\section{Anomalies and Abolition of the Transatlantic Slave Trade}

William Wilberforce's famous 1789 speech to the House of Commons calling for abolition of the slave trade vigorously contested claims that fresh imports of Africans were necessary to ensure the continued prosperity of the West Indies. Wilberforce insisted that 'a variety of individuals, by good usage, have more than kept up their stock' and 'the very numbers in the gang may be kept up by procreation.' ${ }^{2}$ Although the individuals in question were not identified, a group of Barbadian planters - of whom Sir Philip Gibbes is the most prominent - may have been uppermost in mind. These owners had proposed, in two influential treatises published in 1786, that natural increase was not only possible on a sugar estate but constituted the only true test of the care of an enslaved population. Alternatively, the reference could have originated from James Ramsay, who supplied Wilberforce with briefings and in his own tract of 1788 cited the following example: 'Carlisle's plantation in Antigua has been long overstocked from the births.' Ramsay, in turn, was a correspondent of Thomas Clarkson, who in 1787 drew his attention to a Jamaican estate where a former North American Loyalist reported a healthy surplus of births over deaths. In the 1790 parliamentary session, a Select Committee similarly heard evidence that nine other estates - scattered across Jamaica, Antigua, St Croix, and St Domingue - had achieved the same feat. ${ }^{3}$ Returning to his theme in a further oration delivered in 1791 , Wilberforce named three planters - Wilcock, Ottley, and Sir Ralph Payne - achieving population increase through 'melioration'. By now he was sufficiently confident to declare that: 'The instance of estates which, in the evidence appeared to have kept up their numbers, were very many, and almost always to be accounted for from some circumstance of good treatment. ${ }^{4}$ 
For Wilberforce, the political and moral case for reform was buttressed by the British West Indies' ability to sustain slave numbers. His 1789 speech compounded the tragedy of African captivity and the sufferings of the Middle Passage by postulating that a well-treated enslaved population would multiply. Philosophically, Wilberforce sought to reconcile 'the dictates of conscience, and the laws of God' with verifiable fact. By assuring the West Indies that the slave trade was no longer necessary, Wilberforce avoided the repugnant conclusion that 'the same Being who forbid rapine and bloodshed, had made rapine and bloodshed necessary to the well-being of any part of his universe.' To persuade others of the validity of his arguments, the parliamentary address anchored conclusions to data, as if attempting to persuade an impartial spectator of their correctness. ${ }^{5}$ Yet the evidence advanced was problematic. Selecting Jamaica as the lead example, Wilberforce conceded that without imports the colony's slave population would have declined. He nevertheless maintained that the since 1761 rate of loss had decelerated. Adjusting for the effects of the American Revolutionary War (1776-83) and the 1780 hurricane, he inferred that Jamaica's slaves had attained natural increase. Barbados was the other sugar producer selected for detailed analysis but discussion of these data was relegated to the section summarising the resolutions laid before the Commons. The decision reflects the fact that the numbers presented also exhibited an excess of deaths over births. Subsequent historical research has reached markedly different conclusions about these two colonies. Barry Higman demonstrates that of the sugar colonies, 'only Barbados managed to maintain a positive natural increase, a position it probably achieved by about 1810.' In contrast, Jamaica recorded a persistent surfeit of deaths over births and experienced a deteriorating rate of natural decrease. ${ }^{6}$ 
Wilberforce's reading of the demographic data available to him was thus highly optimistic. His 1791 oration, re-introducing abolition, abandoned this approach, electing instead to base conclusions on black populations that were reproducing successfully. In addition to Africa itself and the United States, Wilberforce's selected examples included St Vincent's Black Caribs and Jamaica's Maroon, free black, and mixed-race communities. For sugar plantations, the evidence remained limited to the 'positive testimony' of particular estates and parishes. Wilberforce extrapolated from these cases to sustain his argument that natural decrease had either fallen to a trifling rate or given way to increase. The 1791 speech documented a litany of serious impediments to more widespread reproduction: weak family bonds, promiscuity and alcohol abuse, poor treatment (especially on the part of estate managers), insufficient diet, over-work, and inadequate medical care. Improvement in any one of these areas, Wilberforce maintained, was sufficient to overturn a demographic deficit. Continued commitment to natural increase partly reflects his strong evangelical determination to avoid repugnancy. It also underlines the attractiveness of planter-led, gradualist amelioration: a concept accepted by both leading advocates of abolition and their proslavery opponents. ${ }^{7}$

\section{Anomalies and Emancipation in the British West Indies}

Once the slave trade had been ended by legislation, abolitionists envisaged that slavery would be reformed (and natural increase achieved) through the actions of individual owners. Amelioration was conceived of in incremental terms with reform local to each colony and taking place largely at the level of the plantation. In a fresh parliamentary speech of 1792 , Wilberforce looked forward to the harshness of their present bondage being transformed into the mildness of patriarchal servitude'. ${ }^{8}$ The 
process of change is consistent with principles conventionally associated with Adam Smith: sympathy conjoined with self-interest (the 'invisible hand'). Abolition was expected to promote both fellow-feeling and to encourage planters to take a longerterm view of profit, without the need for further regulation or state intervention to reshape existing institutions. Wilberforce in 1791 criticised planters for their 'utter inattention' to slaves as 'moral agents' and lamented how self-interest was at present 'a remote, feeble, or even a dubious impulse.' Ending the slave trade, he concluded, would remedy these failings. ${ }^{9}$

Post-1807, the demographic improvement Wilberforce and others anticipated failed to materialise in the sugar colonies, with the exception of Barbados. Exploration of the reasons lies beyond the scope of the present paper. One consequence of abolition, however, was to raise incentives to allocate women to field labour, with adverse consequences for the likelihood that females would survive to the end of their child rearing years, and also for their reproductive ability. ${ }^{10}$ After the 1815 Slave Registration Act made comparative data more readily available, the theme of demographic failure was articulated forcibly by James Stephen - one of the chief sponsors of this legislation. Stephen pointed to high mortality among field slaves that could not be made up for by fertility. Comparing West Indian decline with the high rates of natural increase exhibited in the USA, he explicitly linked sugar cultivation to the Caribbean's population deficit. Historical studies have corroborated his general finding in all colonies where sugar was the dominant plantation crop, while noting regional, temporal, and estate-specific variation. ${ }^{11}$ From the 1820 s onwards, the most radical opponents of slavery campaigned first for tighter metropolitan regulation of conditions on plantations, beginning with Thomas Fowell Buxton's 1823 metropolitan slave code. 
This was followed by calls for outright emancipation. For Buxton, who succeeded Wilberforce as the lead reformer, diminishing population remained 'the best of all tests of the condition of the Negro.' ${ }^{12}$ Even on colonies characterised by a persistent surplus of deaths over births, however, some estate populations proved viable demographically. Buxton's critics drew on these anomalies in an attempt to turn 'the best of all tests' back against the emancipationists, just as the early reformers had used anomalies to justify the case for gradual reformation. While campaigners identified themselves as occupying pro- or antislavery positions, their responses to the conditions of slavery and the state of colonial societies possessed significant common features. Representatives of both groups shared a continued commitment to amelioration, particularly during the two decades prior to enactment of the Slavery Abolition Act. Contributors differed, however, in their estimation of planters' capacity to achieve improvement over an acceptable timescale without metropolitan intervention. Natural increase was accepted by participants as a key metric with which to gauge progress. ${ }^{13}$

\section{Grand Sable's Foundation}

Grand Sable was established by Thomas Browne (1750-1825), son of alum and coal merchant of Whitby, Jonas Brown. The Brownes were a prosperous mariner family claiming descent from Sir Anthony Browne, $1^{\text {st }}$ Viscount Montagu (1528-92). ${ }^{14}$ Remarkably, St Vincent represented Thomas' fourth significant colonial investment. In 1774, Browne established a settlement in Georgia's piedmont region, called Brownsborough, financed with $£ 3,000$ of family capital. Soon afterwards, however, he became embroiled in the escalating imperial crisis. Targeted by the Sons of Liberty, 
Browne suffered an atrocious physical assault. As a consequence of fighting on the Loyalist side during the American Revolutionary War (1776-83), he lost his Georgia landed property, taking refuge in St Augustine, East Florida, with approximately 170 slaves. Hopes of establishing a new plantation here were dashed by the post-war secession of Florida to Spain. In recognition of his wartime efforts and losses, however, the British Government conveyed extensive tracts of land to Browne on the Bahamian islands of North and Middle Caicos in 1789 and 1790. These awards led to the creation of thirteen plantations, scattered over 8,000 acres, on which cotton was raised and cattle tended through the labours of more than 600 slaves. $^{15}$

In March 1802, three years after father Jonas' death, Browne returned to Britain. Concerned by poor agricultural conditions and alarmed by security in the wake of the St Domingue slave rebellion (1791-1803) and deteriorating British diplomatic relations with France, he sought exit from the Bahamas. With the assistance of a patronage network that extended as far upwards as Prime Minister William Pitt, Browne petitioned for a substitute grant in St Vincent and in November 1804 was awarded 6,000 acres. The territory consisted of land on the island's Windward side, seized from the Kalinago people (or Black Caribs) at the conclusion of the $2^{\text {nd }}$ Carib War (17957). ${ }^{16}$ About one-third of this grant was suitable for cane planting, a further third fit for pasture, while the remainder contained timber resources. The area's potential economic value was enhanced greatly by the presence of six rivers providing waterpower for crushing mills. ${ }^{17}$ On arrival at St Vincent in 1806, however, Browne discovered that the lots making up his award were also claimed by fourteen 'war veterans' holding letters patent granted by Governor William Bentinck. These occupants had commenced land clearance and begun establishing sugar estates. 
Among the rival claimants were the following leading planters of St Vincent: John and Alexander Cruikshank, Robert Sutherland, Thomas Patterson, and Alan Ross. ${ }^{18}$

A land survey conducted in 1807 and 1808 by John Douglas, on the instruction of Governor George Beckwith, divided the disputed territory into large parcels of land out of which the estates of Grand Sable, Langley Park, Mount Bentinck, Rabacca, Lot 14, Waterloo, Orange Hill, and Tourama eventually emerged (Figure 1). These properties comprised eight of the finest agricultural holdings on St Vincent. The competing claims were eventually resolved in an agreement binding the parties. Established planters were permitted to retain possession of lands already settled in return for payments amounting to $£ 60,000$. Approximately half of this amount was used to indemnify Browne, whose original grant was reduced to 2,330 acres. During the negotiations, one of the occupiers, John Gerald Morgan, also ceded 1,700 acres to Browne on which Grand Sable was laid out in return for a side payment of $£ 5,450$. Governor Sir Charles Brisbane (who succeeded Beckwith) docked 40 acres from Browne's total grant to establish a military fort at Mount Young and preserve natural forest cover in the belief that this environmental measure would help sustain rainfall levels. The colonial authorities retained the further option to lop 132 more acres from Grand Sable to establish a town and church within the newly formed Parish of Charlotte. In 1812-13, Georgetown was duly created after this clause was invoked. ${ }^{19}$

[Figure 1 about here] 
Grand Sable's early development is documented in the annual crop returns for St Vincent (Figure 2). In 1804, 50 slaves produced 3,000 lbs of cocoa from 80 acres of cultivated land. The location of the cocoa walk (or plantation) on higher ground, is marked on the 1807 survey. Cocoa plants take up to five years to mature, indicating some land clearance commenced prior to the first recorded crop, probably undertaken by Samuel Clapham (part-owner of the neighbouring Mount William estate) who in 1798 was cultivating a small portion of the plot. ${ }^{20}$ Douglas' survey, completed in February 1808 , delineates 100 acres planted in cane on the flattest part of the estate: an area lying between the great house and the coastal road. The works, slave village, and coastal warehouses were also all established by this date. Sugar and rum production, the crop returns record, commenced in 1808. In the following year, the estate reached full operating capacity with an enslaved population numbering 660 the largest on St Vincent.

[Figure 2 about here]

Although Browne received free land from the Crown, major investment was required to relocate from the Bahamas and develop his St Vincent property fully. In addition to the expense of establishing sugar cultivation, slaves laboured in 1815 to cut a remarkable 360-foot passageway, known as Black Point Tunnel, to facilitate transport of Grand Sable’s crop to a wharf at Byera point at a reported cost of $£ 5,000 .{ }^{21}$ Compensation that Browne received in the settlement reached with rival planters provided $£ 24,53710$ s of funding needed for these projects. The cash injection, however, proved inadequate and additional finance was forthcoming from Liverpool 
merchants John and James Moss, who by 1813 had advanced a total of $£ 52,718$ secured by mortgage and future consignments of sugar from Grand Sable. ${ }^{22}$ In addition to sinking capital into developing the estate, Browne also needed money to contest legal cases with his St Vincent opponents, including Governor Brisbane who attempted make further encroachments on his land holdings.

In 1811, Brisbane sought Browne's prosecution for superintending the preparation of forged documents, purportedly signed by Cecil Jenkinson (Secretary to the Prime Minister, Lord Liverpool), instructing the Governor to increase the size of the residual award from 2,258 to 4,278 acres. Browne stood trial for fraud at the Westminster Hall. Although Brisbane's governorship featured a series of controversial disputes with planters, the prosecution's case proved overwhelming with clerks and copiers testifying to production and delivery of the false papers. On 21 February 1812, he received a penalty of two years' imprisonment at Newgate gaol. Browne served his sentence at the King's Bench (primarily a debtors' prison) where two attempts were made on his life. Moreover, the Souffrière volcano's eruption on St Vincent, a couple of months after incarceration commenced, caused significant damage to the estate and compounded his woes. ${ }^{23}$

These difficulties led Browne to put Grand Sable up for sale in September 1812. In the event, however, he elected to sacrifice his Yorkshire property and sold Newton House instead to lessen indebtedness. Three years after release from prison in 1814, Browne quit England for St Vincent and in May 1818 transferred his remaining mortgage of $£ 19,000$ from John Moss to the mercantile partnership of Chauncy, Lang, and Lucas. ${ }^{24}$ 
Relinquishing Newton must have been a difficult decision but the subsequent success of Grand Sable vindicated Browne's judgement. London sugar prices experienced a boom between 1814 and 1815, following the end of the Napoleonic Wars, remaining above 35 s per hogshead until $1819 .{ }^{25}$ The estate's earning power is summarised by in a letter Browne wrote to his brother Jonas in 1821. Annual production was estimated at 500 heavy hogsheads a year, 'worth from 12 to 15 thousand pounds according to demand'. Income from the estate reflected the quality as well as quantity of output. 'The sugar made at my place', Browne observed proudly, 'always finds a ready sale being at the head of the Market \& it is in such request by the Sugar Bakers that they purchase it before it is landed from the ships.' One more crop, his brother was informed, was expected to clear all but $£ 4,500$ of accumulated debt. ${ }^{26}$

\section{Pro-Slavery Accounts of Grand Sable's Demographic Success}

Two contemporary accounts of Grand Sable's population growth survive written by the estate's owner, Revd Thomas Alexander Murray Browne (Thomas Browne's son and heir), and his kinsman, Thomas Cayley, who was also employed as the estate's manager. Each presented ammunition for use by the pro-slavery lobby. Cayley's analysis is contained in a letter to Edward Smith-Stanley, $14^{\text {th }}$ Earl of Derby, who became Colonial Secretary in April 1833 and introduced the Slavery Abolition Bill the following year. Browne's observations form part of a lengthy memorial to Sir William Struth, a former President of the St Vincent Council and the owner of Fancy and Prospect sugar estates on the island. Struth acted as St Vincent's colonial agent, representing the interests of planters to the British authorities. The anti-abolitionist campaigner, James MacQueen, made extensive use of this material in an open letter to the Earl of Derby published in Blackwood's Edinburgh Magazine. A shorter extract, 
describing the manners and customs of the enslaved, also appeared anonymously in other outlets, including Chambers' Edinburgh Journal. ${ }^{27}$

Cayley attributed natural increase to the moderate work regime on Grand Sable, emphasising that less than half a ton of sugar was produced per field slave each season. Ratios of slaves to output feature consistently in amelioration literature. Edward Long argued in 1774 that a proportion of two hogsheads (hhd) of sugar to three slaves 'all ages included' was the maximum sustainable ratio in order to maintain numbers through natural increase. Ramsay and Wilberforce both popularised his problematic formula in the late $1780 \mathrm{~s}^{28}$ Cayley postulated that the rise in population was 'not that of mere accident, but of humane treatment, abundance of food and a graduated use of labour adapted to the age, strength and physical capabilities of the labourers.' This statement sought to rebut one of Derby's parliamentary speeches, in which he had stated that maximising sugar production without regard to the welfare of the enslaved resulted in rapid natural decrease. In turning an abolitionist critique on its head, Cayley portrayed growth in the most favourable light, citing a baseline total of only 587 slaves in the 1817 registry. While this source lists this number of individuals as 'belonging' to the proprietor, 13 hired slaves were also present (owned by Margaret Cayley, deceased), alongside a further 29 enslaved persons assigned to Grand Sable. Although these individuals were not all permanently attached to the estate, they were exposed to the same environment and should, therefore, be included in any demographic analysis. 
By attributing natural increase to a benign labour regime and good management, Cayley implicitly endorsed the use of agents such as himself by planters who were non-resident. Abrogation of oversight of slave welfare to managers by absentee owners formed an important strand of abolitionist criticism. Anti-slavery critics objected that owners could not act as patriarchal figures, overseeing amelioration, unless physically present. ${ }^{29}$ The strength of his counter-blast, however, was weakened by the fact that after 1814 the Brownes, unusually for absentees, opted to return permanently to the West Indies and so were on hand to supervise their managers. Thomas Harrison held overall responsibility for the property between these dates, since he signed the slave register return required under the 1815 act. In 1829 , the return was given in by Joseph Latham, indicating that Revd Browne's succession as owner in 1825 was accompanied by a change of manager. ${ }^{30}$

Low work intensity similarly features in Revd Thomas Browne's discussion of population growth. His account notes that only 300 acres were planted in cane: less than an acre for every two slaves and just one acre for every 1.4 working slaves. Exactly the same area, Browne stated, was set aside for provisions, including cottage gardens within the slave village. Sundays and (out of harvest or 'crop time') Thursdays were reportedly given over to growing food, with slaves enjoying the privilege of selling any surplus produce in the island's markets. Browne acknowledged, however, that infant and child mortality rates remained chronic, with fewer than half of all new-borns surviving beyond their tenth birthday. High fertility, in consequence, made a vital contribution to population growth. On Grand Sable, he declared, no fewer than 26 women had five or more living offspring. Between them, these women cared for 143 children. ${ }^{31}$ 
Browne followed Cayley in attributing a high birth rate to the estate's management regime. Pregnant women, he testified, were withdrawn from field work immediately and assigned only light duties after the first trimester. Post-delivery, 'maternity leave' of seven to eight weeks was granted, followed by a further eight weeks of moderate labour before returning to the field. On each child's birth, mothers received 'Baby Linen consisting of 2 shirts 2 caps and 2 Napkins with some old linen, and from their Master a Blanket - 1 yard of Flannel - a few pins - 6lbs of Salt Fish - 6 lbs of Sugar - 2 Bottles of Rum, and 1 Bottle of oil for a Lamp.' Nurses and midwives of infants surviving three weeks were rewarded with cash payments of $16 \mathrm{~s} .6 \mathrm{~d}$. and $8 \mathrm{~s}$. $3 \mathrm{~d}$. respectively. Mothers additionally received £2. 9s. 6d. if a baby survived as long as fifteen months, followed by a further $16 \mathrm{~s}$. $6 \mathrm{~d}$. once their son or daughter joined the children's gang, usually between the ages of six and seven. High fertility was also recognised in the estate's work allocation model:

'Women with only 1 or 2 children generally work about $6 \frac{1}{2}$ hours a day - those with 3 or 4 children work 5 hours a day, and have one day a week out of Crop, and generally an afternoon in Crop in addition to the Sunday; - those with 5 children work on the average 5 hours a day, in \& out of Crop, and have two whole days a week in addition to their Sundays; - lastly those who have 6 or more children (of which description we have several persons on the Estate) are privileged \& exempted by their master from all labour on his Estate.'

These maternity policies echo advice published by Gibbes in 1796 and reforms introduced by other planter advocates of amelioration, including Joseph Foster Barham, owner of the Jamaican estate of Mesopotamia. Barham and Browne agreed that slave welfare ought to be prioritised over the maximisation of sugar production in 
order to maintain an estate's long-term sustainability, employing the same formulation of patriarchal self-interest as Wilberforce had done..$^{32}$

According to Browne, conditions on Grand Sable were so conducive to natural increase that population growth would have been greater but for the moral failings of the enslaved themselves. Despite praising the inhabitants' receptiveness to religious instruction, he stereotyped the slaves as a group characterised by 'the greatest Indolence - Low Cunning - Lying - Theft - Ingratitude - Intemperance - with the grossest Immorality'. Attempts at popularising marriage, he emphasised, had failed: 'most of them taking each other for better or worse without any Ceremony being performed, and separating again with the same facility.' In consequence, Browne concluded that the three greatest checks to population growth were the following:

' $1^{\text {st }}$ \& principally a promiscuous intercourse of the sexes and that at a very early \& immature age; - $2^{\text {dly }}$ an intemperate use of ardent spirits, which they can readily procure at a trifling price, Rum being less than 1s/ sterling per gallon; - and $3^{\text {dly }}$ Quakery in medicine of which the Negroes are too fond. Under which latter head I comprehend not merely a too frequent use of powerful medicines, but of improper ones, such as Nostrums prescribed by the old women, no doubt with the best intentions, or the application of poisonous herbs - intentional inoculation for the Yaws - dirt eating \&c to superinduce sickness, or some virulent sore that may exempt them from work.'

References to moral rectitude can also be found in the writings of both pro- and antislavery campaigners. Wilberforce himself refers to the 'dissolute manners' of the enslaved but held planter attitudes responsible, particularly the failure to view Africans sympathetically as fellow human beings and also inadequate encouragement of monogamy and marriage. The significance of Browne's commentary lies, therefore, in 
his insistence that slaves continued to resist civilising influences and were consequently unfit for emancipation. ${ }^{33}$ In private correspondence with Charles Shephard (a fellow-commissioner alongside Struth), Browne dismissed enslaved Africans as 'the idlest \& most worthless race in existence.' Grand Sable's black population, he alleged, attended church indifferently, cared little for the Sunday school 'when the novelty is over', and failed to appreciate efforts 'to facilitate \& lighten their labours.' Browne was convinced, therefore, that emancipation would end profitable cane cultivation, 'ruin the Proprietors if not endanger their lives', and reduce the enslaved African to an 'original state of Barbarism and Heathenism from which he is just beginning slowly \& gradually to emerge. ${ }^{34}$

\section{Demographic Analysis}

Prior to the first slave registry of 1817 , information about Grand Sable's population is restricted to the summary totals given in to the colony's annual crop returns. A sharp decline in numbers points to a surplus of deaths over births (although figures of purchases, sales, and manumission are omitted in this source). The population fell in size from 660 in 1809 to 578 by 1813 , before recovering to 598 in 1816 . Conditions were typically harsh during a sugar estate's settlement phase: land clearance exacted physical demands on a workforce introduced into a hostile disease environment. Further mortality probably occurred as a consequence of the 1812 eruption and its aftermath, although the drop in numbers in $1813(-21)$ was the same as in $1811(-21)$ and better than in 1810 (-39). Browne's financial plight, coupled with interruptions to trade during the Napoleonic wars (1803-15) must also be considered. High food prices and dire financial straits very likely impaired Thomas Cayley's ability to purchase 
supplies of salted fish, beef, pork, rice, and flour - items providing vital supplements of protein, calcium, and iron to slave diets on Caribbean plantations. ${ }^{35}$

After 1816, Grand Sable's population history can be examined in more detail courtesy of the slave registers. Compared with the earlier period, conditions appear far more favourable. The number of enslaved person rose from 609 in March 1817 to 688 by December 1830. This gain under-states Grand Sable's reproductive achievement, however, since births (395) during the interval greatly exceeded deaths (281). The estate's expansion occurred despite the emancipation of 22 slaves, the sale of a further three (possibly linked to manumissions), the escape of two more, and the transportation off the colony of one other (perhaps as a penalty for repeated absconding). Only five purchases were made to compensate for these losses, while a further five individuals were imported from the Bahamas.

The two key determinants of natural increase are births and deaths. Hence, demographic analysis was undertaken to establish: firstly, how the hazard of death on Grand Sable compared with mortality risk on other estates on St Vincent; and, secondly, whether the estate's fertility rate differed from that recorded for other enslaved populations on St Vincent and across the British West Indies more generally during the early nineteenth century. If all slaves were observed in the registers from birth until death, survivorship on Grand Sable could be analysed by calculating the proportion of individuals reaching a given age and dividing this by the number of slaves born. Repeating the exercise for all ages and comparing the results would generate a survival function: the probability of living from birth until any particular age. 
Unfortunately, this approach is not feasible since members of the enslaved population are only observed for a limited period in the registries. The sample is both left truncated (some individuals are first observed at an age older than infancy, while others are transferred on to the estate at older ages) and right censored (not all individuals are observed until their decease).

It is possible to circumvent this problem by splitting analysis time into intervals defined by the ages at death of subjects and calculating the probability of surviving to a given age (t) as the probability of surviving through all intervals prior to t. Ordering the failure times from lowest to highest, at each failure time period, ti, there are dideaths recorded and a given number of slaves at risk at the beginning of each period, $\mathrm{n}_{\mathrm{i}}$. The KaplanMeier estimator of survival is $\hat{S}(t)=1$ for $t<t_{1}$ and for $t \geq t_{1}$ it is:

$$
S\left(t_{i}\right)=\prod_{t_{i} \leq t}\left(1-\frac{d_{i}}{n_{i}}\right)
$$

The number of slaves in the risk set, $\mathrm{n}_{\mathrm{i}}$, consists of all slaves alive on the estate or who die during each age interval. Left-truncated slaves enter at their age of arrival, while right-censored slaves exit ('fail') for reasons other than death, such as sale, manumission, or flight. The resulting survival function for Grand Sable can be compared with that of other estates within the colony and a statistical test applied to test the null hypothesis that the survival functions are the same.

Not all estates enumerated in the register returns record precise dates of birth and death. In addition to Grand Sable, only seventeen plantations (out of more than 100 
estates operating on St Vincent) have returns of sufficient quality in both the first return of 27 March 1817 and the second submitted on 31 December 1821. The number with acceptable records diminishes further in later returns, restricting the analysis period to the 4.76 year interval between the first two registers. Nevertheless, the sampled estates closely resemble St Vincent's total population in terms of the proportion of slaves who were African-born, the sex ratio, and the age structure. ${ }^{36}$ Although large properties in Charlotte are over-represented, this is not a major concern since Grand Sable itself was located in this parish. The mortality dataset consists of 4,720 individuals (749 slaves belonging to Thomas Browne) and includes a total analysis time of 18,907 person years at risk. 724 deaths are recorded in the registries, of which 71 occurred on Grand Sable.

The slopes of the two survival functions (Figure 3) enable a comparison to be made between the probability of death at $\mathrm{t}$ (conditional on survival to $\mathrm{t}$ ) on Grand Sable and the sample of 17 other estates. To ease interpretation, age specific probabilities of dying are also estimated, which are denoted by $q_{x}$ in Table 1 . These are the proportion of a birth cohort expected to die between each age interval $x$ and $x+n$, (that is, deaths divided by the number of persons alive at age $\mathrm{x}$ ). The null hypothesis that the two slopes are equal is rejected better than $99 \%$ confidence while the life table reveals that age specific mortality was lower on Grand Sable at nearly all ages.

[Figure 3 and Table 1 about here] 
Repeating the analysis confining the sample to Charlotte's Parish generates similar results. If the dataset, however, is further restricted to those estates occupying Browne's land grant (Grand Sable, Lot 14, and Rabacca) the difference between the survival functions disappears (Figure 4). In all of the survival functions, the hazard of death is highest at the youngest ages where the gradient of the curve is steepest. At older ages, survivorship varies according to location. This finding indicates that common factors rendered infancy risky regardless of where a child was born on St Vincent. Conditional on surviving to age five, the prospect of living to older ages was relatively favourable on Grand Sable, Lot 14, and Rabacca. In turn, this suggests that conditions common to the area formerly reserved to the Caribs were conducive to low mortality.

[Figures $3 \& 4$ about here]

Unfortunately, the surviving records do not identify what these circumstances were. While the possibility of a relatively benign local disease environment cannot be rejected, there are no known epidemiological differences between Charlotte's Parish and the rest of the island. There is some evidence, however, that large land grants improved the availability of easily worked provision grounds for slaves, increasing available nutrition as Cayley and Browne both maintained. The establishment of the small township of Georgetown provided a further incentive for enslaved persons living on adjacent estates to grow food since surpluses could be marketed locally. Douglas' land survey was completed shortly after Grand Sable's. Figure 1 indicates that an area had been set aside for slave provisions grounds even by this early settlement 
date. Douglas also depicts land had cleared for provision grounds and plantain walks, as well as cane fields, on neighbouring plots at a more advanced state of cultivation.

Cayley and Browne's attribution of low mortality to 'abundance of food' and provision grounds thus appears justified. In contrast, their contention that Grand Sable benefitted from relatively low work intensity, as a consequence of the estate's management regime, is grounded on a faulty premise. The argument and supporting data are essentially the same as Wilberforce had set before Parliament in 1789. In his oration, Wilberforce stated that 'Mr Long ... lays it down as a principle, that where there are two negroes on an island to three hogsheads of sugar, there work for them will be so moderate, as to ensure a natural increase. ${ }^{37}$ Cayley and Browne followed abolitionist precedent by citing the ratios of slaves to quantity of sugar produced (less than half a ton per slave) and slaves to acreage in cane (less than an acre per two slaves). These are all, however, measures of average labour productivity (AP). If a production technology exhibits decreasing returns to scale, larger estates will have a lower AP even if they are operated efficiently. In consequence, simple ratios are an unreliable guide to the intensity of labour effort. The proof of this proposition is as follows. Let $Y=$ total productivity, $N=$ land, and $L=$ labour. Utilising a general production function, $\mathrm{Y}=\mathrm{N}^{\mathrm{a}} \mathrm{L}^{\mathrm{b}}, \mathrm{a}>0, \mathrm{~b}>0, \mathrm{a}+\mathrm{b}<1$ (decreasing returns). Let $\mathrm{AP}=$ average productivity. Then: $A P=\left(N^{a} L^{b}\right) / L=N^{a} L^{b-1}$ and $d A P / d L=N^{a}(b-1) L^{b-2}$. Since $\mathrm{b}<1$ (because $\mathrm{a}+\mathrm{b}<1$ ), dAP/dL $<0$, and, therefore, the gradient of AP plotted against $L$ must be downward sloping. The result is not, therefore, consistent with the claim of low work intensity. ${ }^{38}$ 
Turning from mortality to consider fertility, the 1817 registry provides details of Grand Sable's female age structure. Of the 310 women present on the estate, $58(19 \%)$ were between 20 and 25 years old: the ages of peak female fertility. In contrast, only $7 \%$ of female slaves fell into this age-range for the rest of St Vincent, while on the seven neighbouring estates in the former Carib Country the share was $5 \%$. The presence of so many potential mothers in 1817 underpinned the large number of recorded births in the succeeding returns. Since slave registration coincided with a point in the Grand Sable's population history when young women of childrearing age were strongly represented, the estate's demographic performance was partly the result of what Cayley termed 'mere accident'. Reproductive success, however, was not only based on the presence of large numbers of women able to conceive but also reflected the high rates of fertility recorded by female slaves in their early twenties.

Age specific fertility rates (ASFR) permit comparison of childbirth across the reproductive lifespan. To obtain ASFRs for Grand Sable, the number of live births in different age groups was divided by the total number of person years lived in each age range between the registries of 21 March 1817 and 31 December 1830:

$$
A S F R=\frac{\text { number of live births to women in specified age group }}{\text { number of female person years lived in same age group }} * 1000
$$

Fertility rates at the youngest ages of reproduction are major drivers of population growth since lost years of child-rearing early in life cannot easily be recovered by high fertility at older ages. Figure 5 and Table 2 presents estimates of the ASFRs prevailing 
on Grand Sable. The unadjusted rates exceed the colony averages recorded for the enslaved populations of Berbice, St Lucia, and Tobago between 1815 and $1822 .^{39}$ These data are also minimum estimates of fertility because 18 births unattributed to specific women are excluded and no allowance is made stillbirths or babies dying within a few hours or days, who were rarely recorded in the register returns. It is possible to adjust the ASFRs upwards by allocating the 18 additional births to age groups in line with the 383 babies whose mothers are documented and by applying a multiplier derived from Model Life Tables to allow for neonatal mortality. The adjusted ASFRs suggest that fertility peaked at more than 300 per 1,000 for women aged between 20 and 24, and remained well above 250 for females until the end of their thirties. Even the unadjusted rates are very high and exceed the range of 245 to 250 for the age range 20-29 commonly encountered in many present-day developing countries.

[Figure 5 and Table 2 about here]

The total fertility rate (TFR) estimates the total number of births a representative woman is expected to have based on a population's ASFR, assuming survival to the end of the reproductive lifespan. The rate is worked out as follows:

$$
T F R=\frac{\Sigma A S F R * 5}{1000}
$$

Usually the TFR is calculated as a synthetic rate, but in this case it is akin to a cohort fertility rate since it is based on the experiences of 522 women over nearly 14 years, rather than being a projected life-course based on a single year's information. The 
estate's TFR, based solely on the 1817-30 registry data (without correction), was 8 children with a maternal mean age at birth of 33 years. This fertility measure is comparable to that attained by the black population of the ante-bellum USA. ${ }^{40}$

Grand Sable's demographic success is reinforced by its net-reproduction rate (NRR). The NRR measures the number of surviving daughters born to Grand Sable's female slaves, passing through their lifetimes and subject to the estate's age-specific fertility and mortality rates. A critical value for NRR is one: if $N R R>1$, population growth occurs; conversely, if NRR $<1$ numbers cannot be maintained. During the observation period, 207 daughters were born to women spending a total of 2,068.5 years between ages 15 and 44 . The probability of a woman surviving to age 30 (the mid-point of childrearing) was approximately 57 per cent (utilising the mid-point of the 95 per cent confidence intervals of the female-only survivor function). NRR is related to TFR by the following equation:

$$
N R R=\frac{T F R * p(A m)}{1+S R B}
$$

where $p(A m)$ is the proportion of the female population surviving to the mean age of maternity and SRB is the sex ratio at birth (males/females, assumed to be 105). ${ }^{41}$ Substituting TF8 $=8$ and $\mathrm{p}(\mathrm{Am})=0.57$ into the equation, Grand Sable's NRR is estimated to be 2.2 which is significantly above the critical value required for natural increase.

Rev Browne's account of demographic conditions on Grand Sable was accurate in several respects. He correctly observed that infant mortality, in common with the rest 
of the island, was acute. Conditional on surviving the early years, life expectancy at older ages was however better than on other properties - although not statistically superior to survival prospects on neighbouring estates. Browne also appreciated the significance of high fertility and highlighted the large number of children that enslaved women who survived to the end of their reproductive span might be expected to give birth to. In concentrating exclusively on the demographic benefits conferred by the estate's managerial regime, however, Browne exaggerated the impact of his policy interventions. The agency of the enslaved themselves was discounted, whom he castigated as holding back natural increase through promiscuity, alcoholism, and medical malpractice. A closer examination of the community questions this interpretation.

Aside from a brief allusion to some Creole slaves 'having lived above 50 years in the Family', neither Rev Browne nor Cayley referred to the prior history of Grand Sable's inhabitants. There is compelling evidence that the majority of enslaved persons on the estate at the beginning of the registry period originated from Grand Caicos. Thomas Browne's land grant of 1805 required him to list the 643 slaves inhabiting his Bahamas plantations, authorising their transportation to St Vincent within two years. He was then prohibited from introducing any other slaves, except to replace losses from mortality. Furthermore, he was also forbidden from hiring any enslaved labour except skilled artisans or domestics. Surviving correspondence confirms that all 643 slaves and 15 overseers were transported on three or four vessels in $1806 .{ }^{42}$ Significantly, Browne cited demographic success on Grand Caicos in his lobby to secure land on St Vincent. A memorial, submitted to the Crown, observed that numbers on the plantations were sustained without the need for African replacements, 
owing to 'his attention to the comforts and marriages of the said Negroes.' At his trial, the Attorney General, Vicary Gibbs, recounted that in 1805, during the parliamentary debate over abolition, Browne had emphasised demographic achievements on the Bahamas in his application for a new land grant. 'A large slave gang of between six and seven hundred', Gibbs told the Jury, had been 'placed in a state of increase without any new importations.' He proceeded to credit Browne, 'by his attention to their comforts and to all circumstances which could conduce to their preservation.' The Newgate Calendar similarly noted that 'Colonel Browne represented to the Government that he had a large gang of negroes which he had nurtured with particular care, and had succeeded in reducing them to such domestic habits that they multiplied as fast as by the course of nature they would die off. ${ }^{43}$

In contrast to most other regions of the BWI, the Bahamas attained a positive and rising population growth rate during the decades following abolition of the slave trade. ${ }^{44}$ This region of the Caribbean never cultivated sugar on a large scale, the dominant economic activities at the time of Thomas Browne's move to St Vincent being cotton cultivation and cattle rearing. Low soil fertility and surplus labour within the region also encouraged the emergence of a self-hire system, whereby slaves were able to negotiate work contracts in return for wages which were shared with their owners. Within the plantations, the prevalence of task work (a system whereby slaves were given a specific activity to complete) provided more opportunities to cultivate of provision grounds in 'free time' and market surplus produce. The absence of sugar planting on the Bahamas affected the nature of the demand for slaves, placing less emphasis on importation of prime male field hands. The 1821 slave register for the Bahamas indicates that enslaved family structures were strong and fertility levels high. 
In support of this finding, Craton presents evidence that that 85 percent of individuals belonged to some form of family and 54 percent to a nuclear family. He also reports that two-thirds of women aged between 15 and 49 had living children. ${ }^{45}$

Thomas Browne's relocation provided a mechanism for transferring societal and family structures forged in the Bahamas to St Vincent. After disembarking from a sea crossing in excess of 760 nautical miles, an arduous labour clearing grounds for cane cultivation awaited the former inhabitants of Grand Caicos. Following acute rates of mortality, leading to the loss of many friends and companions, the horrors of a fullscale volcanic eruption were then unleashed upon the community. Collective resilience during the estate's difficult early years enabled the population to survive the transition. The historical records provide scant documentation of the lives and achievements of individuals living within the enslaved community. Tantalising glimpses alone survive. In the aftermath of the later devastating hurricane strike of 1831, for example, Rev Browne records how he prioritised the construction of 'a little Prayer House elevated on a ridge above the Negroe Houses' belonging (his account implies) to one David Small, who is described as 'a worthy old man' and an 'ancient Patriarch'. This figure acted as an arbitrator in disputes and 'enjoyed great influence' within the enslaved community, many of which assembled in his 'chapel' three times a week. Browne describes how David Small was literate and also a man with 'a numerous family - \& long line of Descendants. ${ }^{46}$ In the St Vincent register for March 1817 , fourteen individuals with the surname 'Small' are listed, including a 'Davy Small' whose age was recorded as 48 . Also enumerated is Jenny Small, aged 45 , perhaps his partner or wife. Davy's stated occupation was that of 'labourer' and his colour described as black. As a 'Creole' born in the British West Indies, he knew no other life 
but that of slavery. Nevertheless, Davy Small's resourcefulness rivalled and arguably surpassed that demonstrated in Thomas Browne Sr's own eventful life narrative.

Revd Browne's dismissal of slave commitment to the institution of Christian marriage implies that stable family relations did not develop on the estate. This claim, however, needs to be re-evaluated in the light of both the authors' biases and the Bahamian social context. What is most compelling about the account is the very large numbers of children described as being cared for on Grand Sable. Aspects of his account referring to labour practices are suggestive of other arrangements imported from Grand Caicos. Browne refers, for example, to the introduction of 'various improvements in the arrangement of the fields, and mode of working them.' He stops short, however, of stating that task work was practiced on the estate.

The 1817 St Vincent slave register contains no direct indications that Grand Sable's population originated from Grand Caicos. Of the 608 persons listed whose origin is stated, 206 are described as Africans and 402 as Creoles. The register, however, rarely applied any descriptors to slaves other than these two categories. Of the 21,623 enslaved persons on St Vincent assigned to estates, only 155 were designated as Bahamian. Nevertheless, a comparison with the seven other 'Carib Country' estates reveals that the mean ages of Africans and Creoles on Brown's estate was significantly higher than on neighbouring properties. This finding is consistent with the enslaved of Grand Sable forming a population that had existed longer as a social unit than the rest of the locality, despite the fact that all eight estates commenced sugar production between 1804 and 1810 . The registration system and policing of abolition placed a bar 
on adding significant numbers of males from Africa or other colonies. Prior to 1807, Tadman and others have shown that planters sought to maintain a male-dominated population to meet the heavy labour demands of sugar cultivation. Grand Sable's demographic structure reflected the different economic circumstances prevailing in the Bahamas, helping to explain the favourable sex ratio noted above. ${ }^{47}$

[Table 3 about here]

\section{Conclusions}

Grand Sable featured in contemporary debates over both abolition and emancipation as a rare example of a self-reproducing slave population. Thomas Browne played up the community's demographic achievement in 1805, capitalising on the campaign to end the slave trade to further his claim for Carib lands on St Vincent. His extensive holding was subsequently developed by transporting slaves from the Bahamas, rather than importing African captives. His son Rev Browne similarly lauded Grand Sable's reproductive success in a rear-guard action against the passage of the Slavery Abolition Act. For Wilberforce, plantations achieving natural increase challenged received opinion that without fresh imports of Africans sugar estates would cease to be sustainable. The existence of anomalies running counter to this view strengthened Wilberforce's belief that commerce in Africans was economically redundant as well as morally repugnant. His forecasts about slavery's demographic prospects postabolition, although mistaken for the BWI as a whole, were correct for Barbados, where 
planter experience of natural increase is documented just a few years prior to his famous oration.

Demographic success provided Rev Browne and Cayley with propaganda for use against emancipationists. Owner and manager happily concurred that natural increase was a valid test of good treatment and argued that its achievement on Grand Sable represented the triumph of skilled planter-ship over slave immorality and idleness. On closer inspection, however, this estate's demographic status tends rather to corroborate Buxton's opinion that failure to achieve natural increase was the norm. Grand Sable's extremely favourable female age structure at the time of the inaugural slave registry left the estate well-placed to buck the general trend. Although both survivorship and fertility levels were relatively high, the reasons cited by Cayley and Browne for these achievements are questionable. Although both commentators referred to availability of nutrition, they placed insufficient weight on the agency of the enslaved in producing food surpluses, choosing instead to explain natural increase as the product of a paternalistic management regime. Browne also failed to give sufficient credit to the leadership structures and agency within the black population in negotiating the fraught translation from the relative stability of the Bahamas to the far more dangerous setting of St Vincent. 


\section{Figures and Tables}

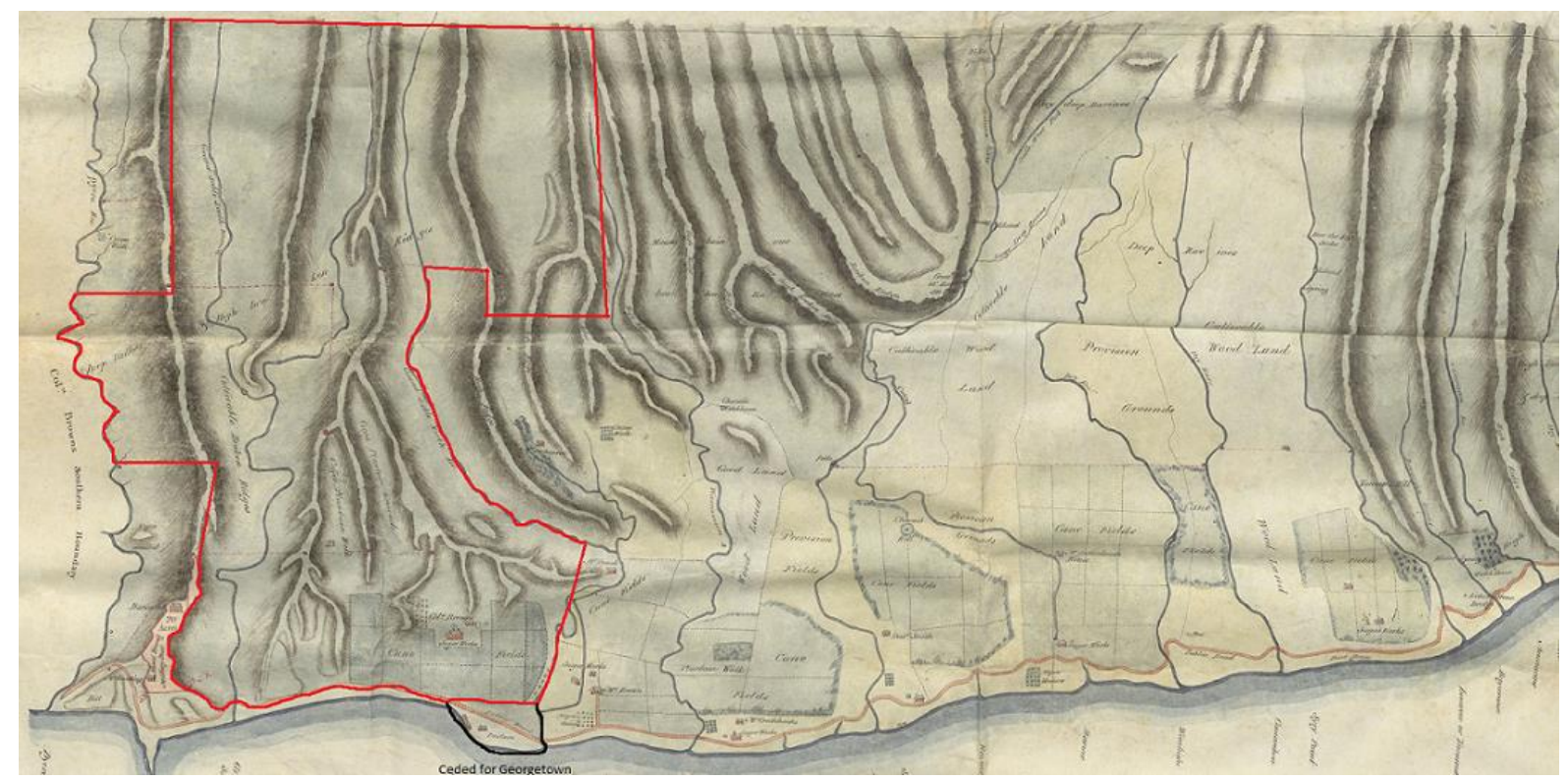

Figure 1: Copy (date unknown) of John Douglas' 1807 survey of Thomas Browne's Carib land grant with the 1873 border of Grand Sable superimposed (red boundary) and marking the location of Georgetown. Source: The National Archives[TNA] (London), TS $11 / 1,078 / 1$. For comparison, see John Thompson's 1856 copy of Douglas' survey, TNA, CO 441/10/3. 


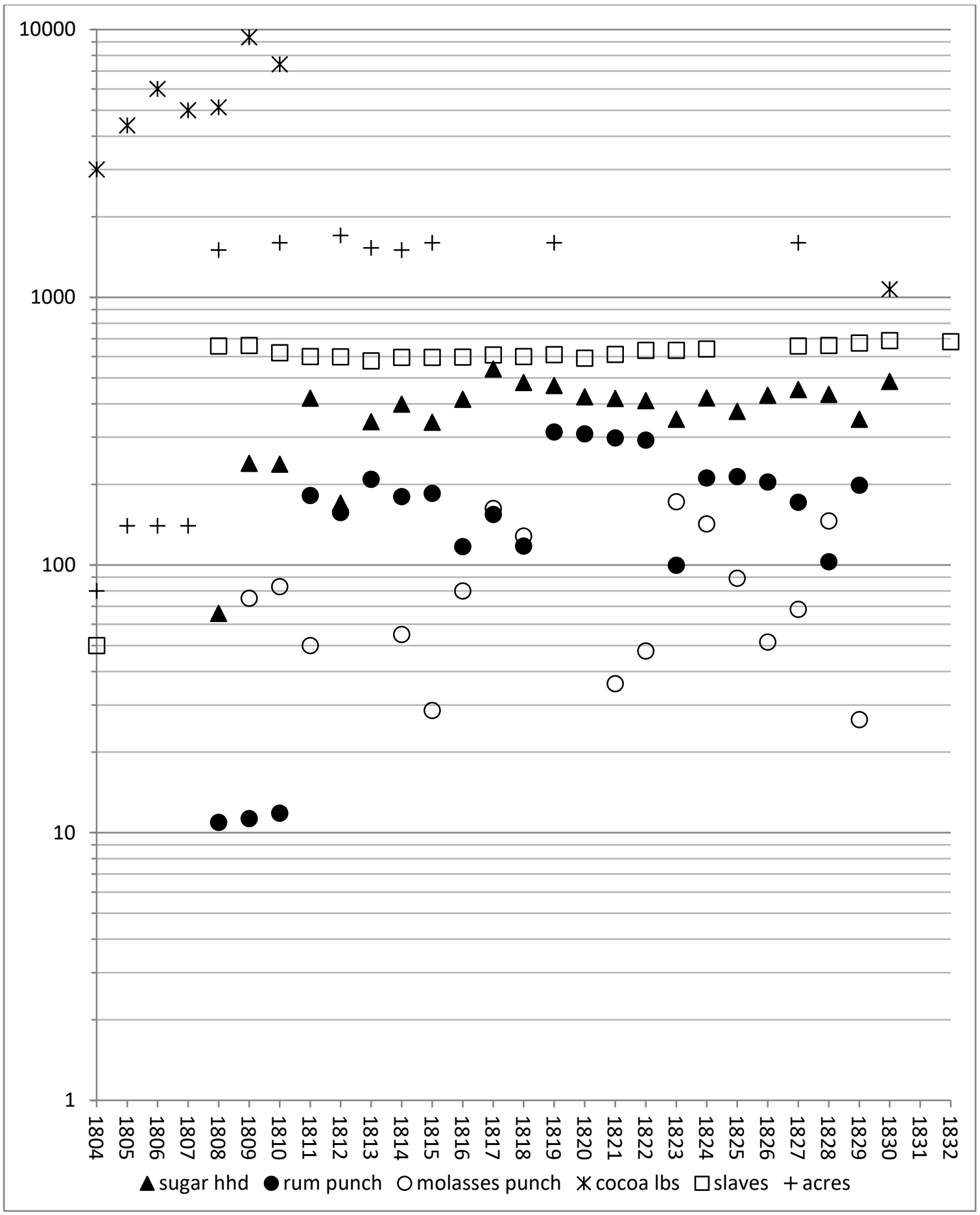

Figure 2: Development of Grand Sable Estate, 1804-30. Sources: Pocket book listing produce returns for St Vincent and the Grenadines between 1801 and 1814, accessioned with An Almanack Calculated for the Island of St. Vincent (Kingstown: St Vincent, 1808 \& 1809), Bodleian Library of Commonwealth and African Studies at Rhodes House, University of Oxford, RHO Retro Staff; An Account of the Number of Slaves Employed, and Quantity of Produce Grown, on the Several Estates in the Island of Saint Vincent and its Dependencies, from the year 1801 to 1818; and from that period to 1824, inclusive. Compiled from the official returns. (Kingstown: St. Vincent, 1825); Charles Shephard, An Historical 
Account of the Island of Saint Vincent (London, 1831) appendix, vi-xxvi; 'Valuation of produce made at Grand Sable Estate as fixed by the annual tax acts from its first settlement in 1808 to 31st December 1827', return in the possession of Charles Armstrong (private correspondence with the author); Blackwood's Edinburgh Magazine, vol. 34 (1833), 237; TNA: CO260/49, 'Reply, to the Queries put by the Committee appointed to correspond with Sir William Struth by the Rev ${ }^{d}$ Thomas Alexander Browne, Sept $15^{\text {th }} 1832 . '$

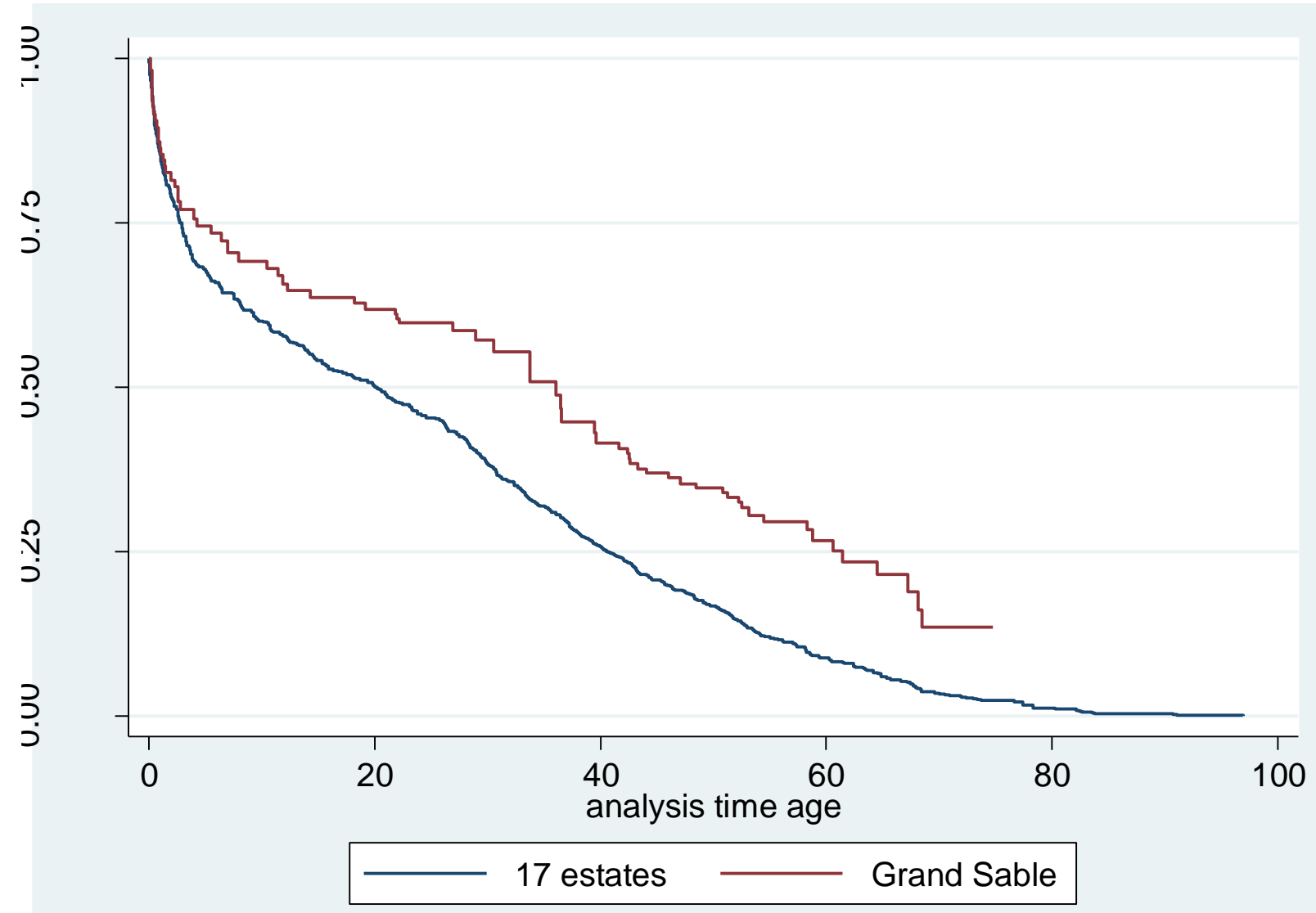

Figure 3: Comparison of Grand Sable's survival function with that of 17 other estates, 181721. Log-rank test for equality of survival functions: $\operatorname{chi}^{2}(1)=20.56, p=0.000 * * *$. 


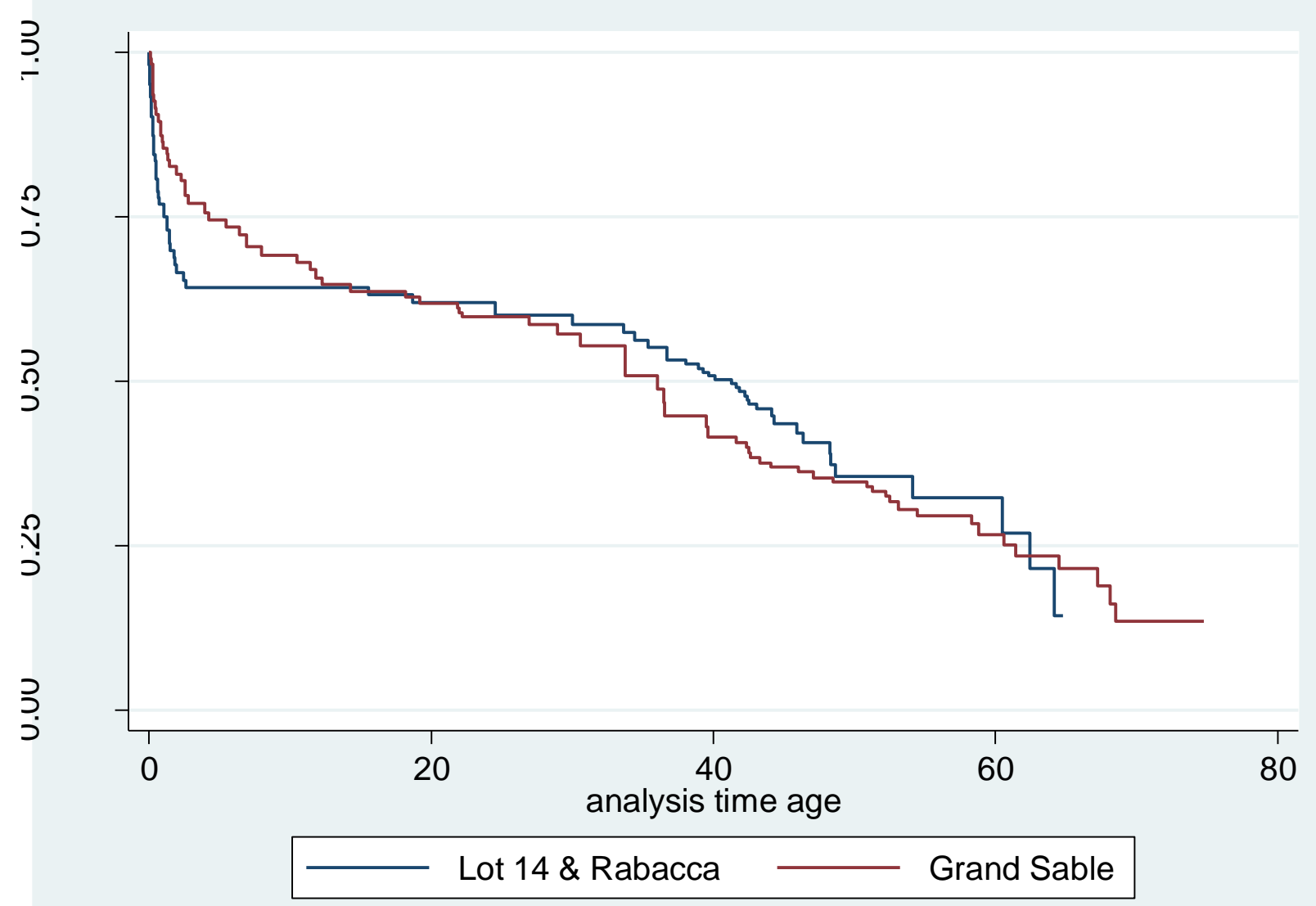

Figure 4: Comparison of Grand Sable's survival function with that of Lot 14 and Rabacca, 1817-21. Log-rank test for equality of survival functions: $\operatorname{chi}^{2}(1)=0.33, p=0.565$. 


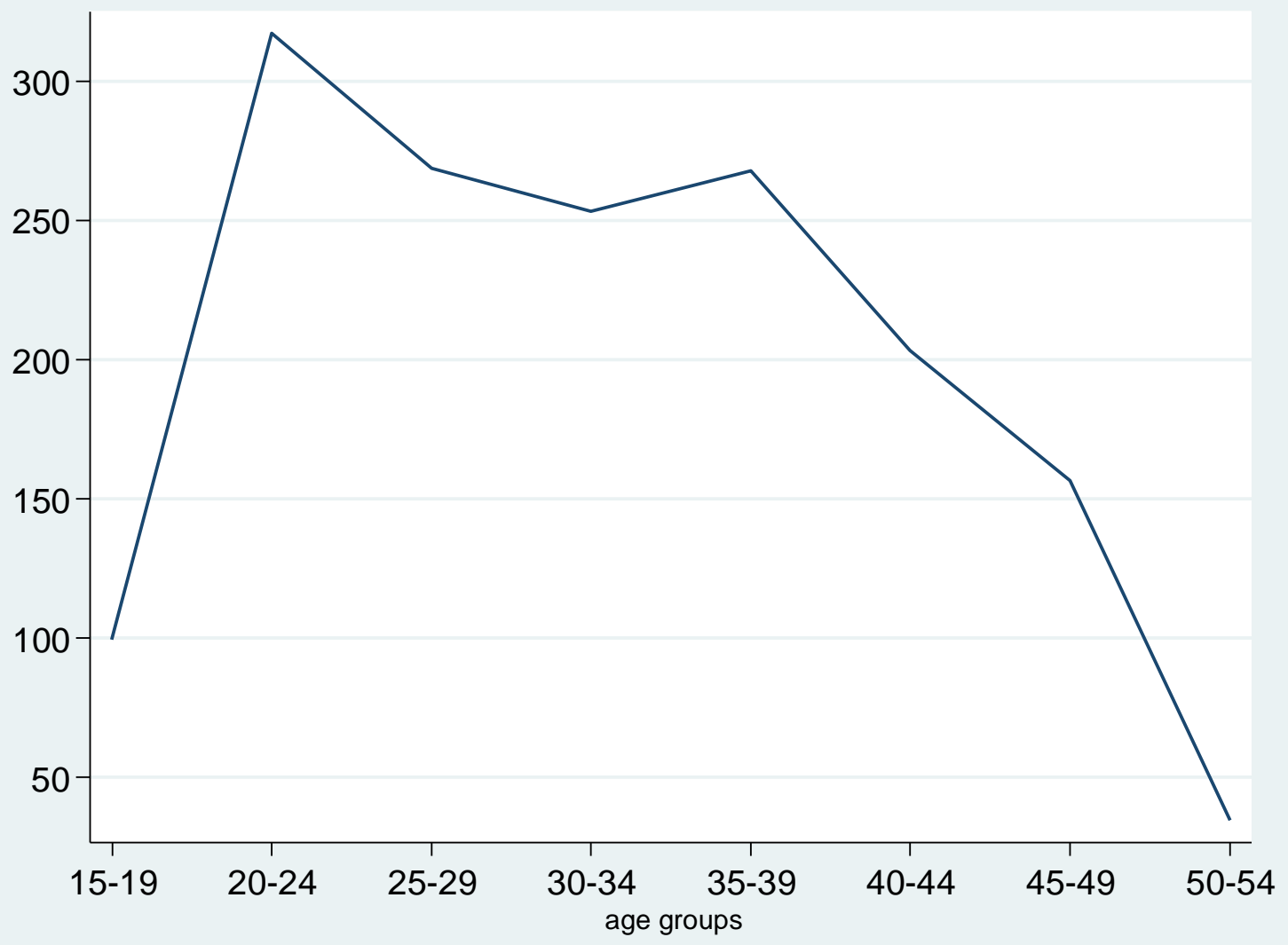

Figure 5: Age specific fertility rates on Grand Sable, 1817-30. $\mathrm{N}=383$ births including 6 sets of twins. Excludes 18 births that could not be matched to mothers. 


\begin{tabular}{|c|c|c|c|c|}
\hline \multicolumn{5}{|l|}{ Grand Sable } \\
\hline Age groups $(x)$ & Deaths & $I_{x}$ & $\mathbf{p}_{\mathrm{x}}$ & $q_{x}$ \\
\hline 0 to 5 & 25 & 1.000 & 0.745 & 0.255 \\
\hline 5 to 10 & 4 & 0.745 & 0.928 & 0.072 \\
\hline 10 to 15 & 5 & 0.691 & 0.921 & 0.079 \\
\hline 15 to 20 & 2 & 0.637 & 0.972 & 0.028 \\
\hline 20 to 25 & 3 & 0.619 & 0.966 & 0.034 \\
\hline 25 to 30 & 2 & 0.598 & 0.957 & 0.043 \\
\hline 30 to 35 & 2 & 0.572 & 0.888 & 0.112 \\
\hline 35 to 40 & 5 & 0.508 & 0.817 & 0.183 \\
\hline 40 to 54 & 6 & 0.415 & 0.890 & 0.110 \\
\hline 54 to 50 & 3 & 0.369 & 0.938 & 0.062 \\
\hline 50 to 55 & 6 & 0.347 & 0.851 & 0.149 \\
\hline 55 to 60 & 2 & 0.295 & 0.905 & 0.095 \\
\hline 60 to 65 & 3 & 0.267 & 0.805 & 0.195 \\
\hline 65 to 70 & 3 & 0.215 & 0.625 & 0.375 \\
\hline 70 to 75 & 0 & 0.134 & & \\
\hline \multicolumn{5}{|l|}{17 Estates } \\
\hline Age groups ( $x$ ) & Deaths & $I_{x}$ & $\mathbf{p}_{x}$ & $q_{x}$ \\
\hline 0 to 5 & 127 & 1.000 & 0.679 & 0.321 \\
\hline 5 to 10 & 40 & 0.679 & 0.885 & 0.115 \\
\hline 10 to 15 & 35 & 0.601 & 0.899 & 0.101 \\
\hline 15 to 20 & 19 & 0.540 & 0.925 & 0.075 \\
\hline 20 to 25 & 24 & 0.500 & 0.907 & 0.093 \\
\hline 25 to 30 & 43 & 0.453 & 0.847 & 0.153 \\
\hline 30 to 35 & 62 & 0.384 & 0.832 & 0.168 \\
\hline 35 to 40 & 66 & 0.319 & 0.808 & 0.192 \\
\hline 40 to 45 & 63 & 0.258 & 0.802 & 0.198 \\
\hline 45 to 50 & 42 & 0.207 & 0.807 & 0.193 \\
\hline 50 to 55 & 52 & 0.167 & 0.719 & 0.281 \\
\hline 55 to 60 & 19 & 0.120 & 0.733 & 0.267 \\
\hline 60 to 65 & 22 & 0.088 & 0.672 & 0.328 \\
\hline 65 to 70 & 13 & 0.059 & 0.580 & 0.420 \\
\hline 70 to 75 & 10 & 0.034 & 0.691 & 0.309 \\
\hline 75 to 80 & 3 & 0.024 & 0.464 & 0.536 \\
\hline 80 to 85 & 6 & 0.011 & 0.255 & 0.745 \\
\hline 85 to 90 & 2 & 0.003 & 1.000 & 0.000 \\
\hline 90 to 95 & 1 & 0.003 & 0.321 & 0.679 \\
\hline 95 to 100 & 0 & 0.001 & & \\
\hline
\end{tabular}


Table 1: Life Tables for Grand Sable and the sample of 17 estates, using 1817-21 registry data

Notes:

$I_{x}=$ proportion surviving to end of each age interval

$p_{x}=$ proportion surviving to the end of each age interval conditional on surviving to the beginning of each interval

$q_{x}=$ proportion dying during each age interval $\left(1-p_{x}\right)$.

\begin{tabular}{|l|r|r|r|}
\hline Age groups & ASFR & Births & $\begin{array}{r}\text { Person years in each age } \\
\text { group }\end{array}$ \\
\hline 15 to 20 & 99.7 & 20 & 200.7 \\
\hline 20 to 25 & 317.1 & 128 & 403.6 \\
\hline 25 to 30 & 268.7 & 116 & 431.6 \\
\hline 30 to 35 & 253.4 & 77 & 303.8 \\
\hline 35 to 40 & 267.8 & 26 & 97.1 \\
\hline 40 to 45 & 203.3 & 8 & 39.4 \\
\hline 45 to 50 & 156.7 & 7 & 44.7 \\
\hline 50 to 55 & 34.6 & 1 & 28.9 \\
\hline & 1601.3 & 383 & 1549.8 \\
\hline & & & \\
\hline IASFR $\times 5$ & 8006.7 & & \\
\hline TFR & 8.0 & & \\
\hline
\end{tabular}

Table 2: ASFRs for Grand Sable, using 1817-30 registry data 


\begin{tabular}{|c|c|c|c|c|c|}
\hline Group & $\begin{array}{r}\text { Grand } \\
\text { Sable } \\
\end{array}$ & $\begin{array}{r}\text { Seven } \\
\text { Estates }\end{array}$ & difference & $\begin{array}{r}\text { Mann Witney } \\
\text { test }\end{array}$ & significance \\
\hline Africans & 42.2 & 37.9 & 4.4 & 0.000 & $* * *$ \\
\hline Creoles & 17.7 & 14.6 & 3.1 & 0.000 & $* * *$ \\
\hline African males & 41.0 & 37.7 & 3.3 & 0.000 & $* * *$ \\
\hline African females & 44.0 & 38.1 & 5.9 & 0.000 & $* * *$ \\
\hline Creole males & 16.3 & 14.6 & 1.7 & 0.024 & $*$ \\
\hline Creole females & 19.0 & 14.7 & 4.3 & 0.000 & $* * *$ \\
\hline
\end{tabular}

Table 3: Comparison of the mean ages (in 1817) in years of Africans and Creoles on Grand Sable and seven neighbouring estates in the Carib Country (Langley Park, Lot 14, Orange Hill, Mount Bentinck, Rabacca, Tourama, and Waterloo). Source: TNA: T71/493. Note: Waterloo's enslaved population was divided to create the separate estate of Orange Hill in 1816. ${ }^{* * *} \mathrm{p}<0.001,{ }^{*} \mathrm{p}<0.05$.

${ }^{1}$ Thomas Kuhn, The Structure of Scientific Revolutions (2nd ed., Chicago: University of Chicago Press, 1970), 52-3; Peter A. Sturrock, 'The Role of Anomalies in Scientific Research', Journal of Scientific Exploration, vol. 21 (2007), 241-60.

${ }^{2}$ The Speech of William Wilberforce, Representative for the County of York, on Wednesday the $13^{\text {th }}$ of May, 1789 , on the Question of the Abolition of the Slave Trade (London: J. Walter, n.d. 1789?), 32.

${ }^{3}$ Edwin Lascelles et. al., Instructions for the Management of a Plantation in Barbadoes and for the Treatment of Negroes (London, 1786), 2; [Sir Philip Gibbes], Instructions for the Treatment of Negroes (London, 1786); James Ramsay, Objections to the Abolition of the 
Slave Trade with Answers (London, 1788), 67; Katherine Paugh, 'The Politics of Childbearing in the British Caribbean and the Atlantic World During the Age of Abolition, 1776-1838', Past and Present, number 221 (2013), 128.

${ }^{4}$ Debate on a Motion for the Abolition of the Slave Trade in the House of Commons $\left(2{ }^{\text {nd }}\right.$ ed. 2 volumes bound as one; London, 1792), vol. i, 27; [William Cobbett] The Parliamentary History of England, from the Earliest Period to the Year 1803 (London, 1817), vol. xxix, column 268. Paugh is the source for Ramsey's briefing of Wilberforce, who cites 'Ramsey, James', Oxford Dictionary of National Biography by J. Watt, http://www.oxforddnb.com/view/article/23086. Wilberforce's 1791 speech referenced Sir Philip Gibbes' observation 'That he should consider it as the fault of the Manager if he did not keep up the number' (Debate on a Motion, vol. i, 41).

${ }^{5}$ Speech of William Wilberforce, 20. On the influence of Adam Smith on Wilberforce, see Anne Stott, Wilberforce: Family and Friends (Oxford: Oxford University Press, 2012), [page].

${ }^{6}$ B.W. Higman, Slave Populations of the British Caribbean, 1807-1834 (2 ${ }^{\text {nd }}$ ed., Barbados, 1995; $1^{\text {st }}$ ed. 1984), 307, 311; Speech of William Wilberforce, 29-30, 60-3; David Lowenthal, 'The Population of Barbados', Social and Economic Studies, vol. 6 (1957), 445-501; David Eltis and Paul Lachance, 'The Demographic Decline of Caribbean Slave Populations: New Evidence from the Transatlantic and Intra-American Slave Trades' in David Eltis and David Richardson, eds., Extending the Frontiers: Essays on the New Transatlantic Slave Trade Database (New Haven, Conn., 2008), 335-363.

7 Debate on a Motion, vol. i, 18-21, 31-2, 40-1; Robert Isaac Wilberforce \& Samuel Wilberforce, The Life of William Wilberforce (5 vols; London, 1838), vol. ii, 440; Paugh, 'Politics of Childbearing', 122, 136, 140-2, 145. 
${ }^{8}$ Debate on a Motion, vol. i, 13.

${ }^{9}$ Christa Dierksheide, Amelioration and Empire: Progress and Slavery in the Plantation Americas (University of Virginia Press: Charlottesville \& London, 2014), 159-62.

10 Martin Forster \& S.D. Smith, 'Surviving Slavery: Mortality at Mesopotamia, a Jamaican Sugar Estate, 1762-1832, Journal of the Royal Statistical Society, Series A, vol. 174 (2011), 924-5; Kenneth Morgan, 'Slave Women and Reproduction in Jamaica, c.1774-1834', History, vol. 91 (2006), 237-8, 253.

${ }^{11}$ James Stephen, The Slavery of the British West India Colonies Delineated As it Exists Both in Law and Practice, and Compared with the Slavery of Other Countries, Antient and Modern Volume 2, Being a Delineation of the State in Point of Practice (London, 1830), 76-7; S.L. Engerman, 'Some Economic and Demographic Comparisons of Slavery in the United States and the British West Indies', Economic History Review, 29 (1976), 267-74; Michael Tadman, 'The Demographic Cost of Sugar: Debates on slave Societies and Natural Increase in the Americas', American Historical Review, 105 (2000), 1,534-75; Higman, Slave Populations, 307-11, 375-77; Higman, 'Slavery and the Development of Demographic Theory in the Age of the Industrial Revolution' in Slavery and British Society, 1776-1846 ed. James Walvin (London: Macmillan, 1982), 164-94.

${ }^{12}$ Higman, Slave Populations, 303-4.

${ }^{13}$ Dierksheide, Amelioration and Empire, 184-9, 209. 
${ }^{14}$ Browne family pedigree, Thomas Alexander Browne Collection, Georgia State Archives [GSA], MS \#73-133, microfilm collection, Drawer 180, box 80.

${ }^{15}$ Edward J. Cashin, The King's Ranger: Thomas Browne and the American Revolution on the Southern Frontier (University of Georgia Press, 1989), 1-2, 18-19, 28-33, 174, 179, 188, 190; Joan Leggett, 'Thomas Browne of Whitby - Loyalist, American Revolution and Gentleman Planter, West Indies', Practical Family History , 67 (2003), [n.p.]; Charlene Kozy, 'Tories Transplanted: the Caribbean Exile and Plantation Settlement of Southern Loyalists', Georgia Historical Quarterly, 75 (1991), 18-42.

${ }^{16}$ [Thomas Browne] to [Jonas Browne Jr], 21 March 1802; W. Hayes Bourne to Thomas Browne, 10 November 1804 [misdated 1803 in the microfilmed transcription], Thomas Alexander Browne Collection, GSA; Despatch, Earl Camden to Governor George Beckwith, 8 June 1805 (copy in the possession of Joan Legatt); Cashin, King's Ranger, 191-2, 196-7, 199.

17 Thomas Browne to Jonas Browne, $10^{\text {th }}$ February 1821, Thomas Alexander Browne Collection, GSA. The rivers are marked on contemporary surveys of the former Carib lands as the Byera, Grand Sable South, Grand Sable North, Warawarra, Rabacca, and Waribishi, TNA, MPD 1/97 .

${ }^{18}$ TNA, TS 11/1,078, 'Statement of the distribution of Thomas Browne's original grant of 6,000 acres and names of the occupants'.

19 TNA, TS 11/1,078/5371, 'Queries contained in Mr Litchfield's letter to Sir Charles Brisbane '[n.d, c.1810-12]; Memorial of the Family of the late Colonel Browne of the Island of St Vincent [n.d., post-1825], Thomas Alexander Browne Collection, GSA; Cashin, King's Ranger, 191-2,196-7,199-200. 
${ }^{20}$ Information provided by Charles Armstrong, private communication, 3 August 2012.

${ }^{21}$ Robert M. Martin, Statistics of the Colonies of the British Empire (London, 1839), 52.

${ }^{22}$ TNA, TS 36/2, 'Examination of William Hill, Treasury Clerk'; CO441/10/3, 'Abstract of certain Deeds \& Documents recorded in the office of the Registrar of Deeds Saint Vincent relating to The Grand Sable Estate.'

${ }^{23}$ Cashin, King's Ranger, 204-11; Andrew Knapp and William Baldwin, The Newgate Calendar; comprising interesting memoirs of the most notorious characters who have been convicted of outrages on the laws of England since the commencement of the eighteenth century; with anecdotes and last exclamations of sufferers (4 vols; London, 1824-6), part III; S.D. Smith, 'Volcanic Hazard in a Slave Society: the 1812 Eruption of Mount Soufrière in St Vincent', Journal of Historical Geography, 37 (2010), 10. For details of another Brisbane controversy (Rucker vs Brisbane), see Virginia Historical Society, Keane Family Papers, Diary of Hugh Perry Keane, Mss 1 K197 a 52, ‘Charges against Sir Charles Brisbane sent to Earl Bathurst' [n.d., c.1818]. Notes of the trial and the prosecution's brief are preserved in TNA, TS 36/2 and TS 11/1,078.

${ }^{24}$ Hull Daily Packet, 22 September 1812; 'A List of Debts due Philip Monoux Lucas Esq in Saint Vincent, 24 June 1813', Cambridge University Library, Add MS 8,369, Lucas Family Papers, Box 2; Cashin, King's Ranger, 214-5.

${ }^{25}$ Price data from Arthur D. Gayer, W.W. Rostow, Anna J. Schwartz, The Growth and Fluctuation of the British Economy, 1790-1850 [microform] : an Historical, Statistical, and 
Theoretical study of Britain's Economic Development (Oxford, Press, 1953), Microfilmed supplement to volumes 1 and 2, pp. 674-9.

26 Thomas Browne to Jonas Browne, $10^{\text {th }}$ February 1821, Thomas Alexander Browne Collection, GSA.

${ }^{27}$ Thomas Cayley to Lord Derby, $4^{\text {th }}$ June 1833, TNA: CO260/51; 'Reply, to the Queries put by the Committee appointed to correspond with Sir William Struth by the Rev ${ }^{d}$ Thomas Alexander Browne Proprietor of Grand Sable Estate in the Island of St Vincent, September 15 1832 ', TNA: CO260/49, 212-21; Blackwood's Edinburgh Magazine no. 209, August 1833; Edinburgh Magazine no. 101, Saturday $4^{\text {th }}$ January, 1834, reprinted in William Chambers \& Robert Chambers eds., Chambers' Edinburgh Journal (2 vols; London, 1834), vol. ii, 327-8 and The Public Ledger and Newfoundland Gazette, $3^{\text {rd }}$ March 1835. On MacQueen, see David Lambert, “The "Glasgow King of Billingsgate”: James MacQueen and the Atlantic Proslavery Network', Slavery and Abolition, 29 (2008), 389-413.

${ }^{28}$ Edward Long, The History of Jamaica (3 vols; London, 1774), vol. 2, 437-8; Ramsay, Objections, 12; Speech of William Wilberforce, 32.

${ }^{29}$ Nicholas Draper, The Price of Emancipation: Slave-ownership, Compensation and british Society at the End of Slavery (Cambridge: Cambridge University Press, 2010), 36-46.

${ }^{30}$ Dierksheide, Amelioration and Empire, 186,198; TNA, T71/493, 495, 497, 498, 499.

${ }^{31}$ Unless another source is indicated, all direct quotations from Revd Thomas Browne are taken from the manuscript account in TNA: CO260/49, 212-21. 
${ }^{32}$ University of Oxford, Bodleian Library, Clarendon Manuscripts, Dep c 428, Letter Book of Joseph Foster Barham II, Barham to Messrs Grant \& Blyth, 4 June 1811; Paugh, 'Politics of Childbearing', 137-8; Speech of William Wilberforce, 24.

${ }^{33}$ Speech of William Wilberforce, 26.

${ }^{34}$ Browne to Charles Shephard, [n.d., 1832?], Thomas Alexander Browne Collection, GSA.

${ }^{35}$ Kenneth Kiple, The Caribbean Slave: A Biological History, (Cambridge, 1984), 26-41.

${ }^{36}$ Estates in the sample: i) Charlotte's parish: Adelphi Exchequer, Grand Sable, Lot No. 14, Mount Grenan, New Prospect, Peruvian Vale, Rabacca, Spring, Three Rivers; ii) St George's parish: Dubois, Mousebank, Cane Garden; iii) St Andrew's parish: Queensbury; iv) St Patrick's parish: Peter's Hope, Westwood, Mount Wynne, Kearton's.

${ }^{37}$ Great Britain, Parliamentary Register, 141.

${ }^{38}$ Analysis of productivity on 108 St Vincent sugar estates during the period 1817 to 1827 indicated decreasing returns to slaves with respect to output, with elasticities of between 0.15 and 0.25 (details available on request) .

${ }^{39}$ Higman, Slave Populations, 359, 682-5.

${ }^{40}$ Michael R. Haines, 'Population Growth in the United States, 1790-1920', in The Cambridge Economic History of the United States, vol. II: the Long Nineteenth Century ed. Stanley L. Engerman \& Robert E. Gallman (Cambridge: CUP, 2000), 158. 
${ }^{41}$ Samuel H. Preston, Patrick Heuveline, \& Michel Guillot, Demography: Measuring and Modeling Population Processes (Malden, MA: Blackwell Publishers, 2001), 115.

42 Grant of land to Thomas Brown: [Secretary of state for the Colonies] to Governor Beckwith, 8 June 1805, manuscript copy in the possession of Joan Leggatt (private communication from Charles Armstrong, 14 August 2012); Cashin, King's Ranger, 200; Charlotte Kozy, 'When Cotton was King: Loyalist Thomas Browne', Times of the Island, 88 (Fall, 2009), [n.p.].

${ }^{43}$ TNA, TS 36/2; Knapp \& Baldwin, Newgate Calendar, part III.

${ }^{44}$ Higman, Slave Populations, 307, 310.

${ }^{45}$ Howard Johnson, 'The Emergence of a Peasantry in the Bahamas during Slavery,' Slavery and Abolition, 10, (1989), 172-86; Michael Craton, 'Changing Patterns of Slave Families in the British West Indies', Journal of Interdisciplinary History, 10 (1979), 8;.

${ }^{46}$ TNA: CO260/49, 212-21, cited in S.D. Smith, 'Storm Hazard and Slavery: the Impact of the 1831 Great Caribbean Hurricane on St Vincent', Environment and History, 18 (2012), 114-5.

47 Tadman, ‘Demographic Cost of Slavery', 1,561-3. 